\title{
FAKTOR PENDORONG DAN PENARIK ORANG BALI BERWISATA KE LUAR NEGERI
}

\author{
Ni Wayan Ana Pradnya Dewi, Made Sudiana Mahendra, \\ Agung Suryawan Wiranatha \\ Universitas Udayana
}

\begin{abstract}
Traveled today has become a lifestyle for the society, including Balinese. During the last few years it was recorded that many Balinese had began a vacation, even to foreign countries. This study aimed to determine the demographic profile of the Balinese and the countries visited, push and pull factors, analyze the level of motivation of the Balinese people and analyze the differences in motivation for the Balinese, who was first to travel abroad and who have often traveled overseas travel. Motivation Theory and Maslow's hierarchy of needs are theories used in this study. Data were collected by interviews and distrubuting questionnaire. Data was analysed with descriptive analysis of qualitative and statistical Discriminant Analysis. The results showed that the motivation of the Balinese are very diverse, respondents may have more motivation than one. The most dominant push factors is the educational opportunity in addition to other motives such as relaxation and play, while the pull factor is the dominant cultural factors, followed by the natural environment, and recreation and attraction services. It was also found the differences in motivation among the people of Bali who for the first time and has frequently traveled overseas travel.
\end{abstract}

Keywords : motivation traveled, Balinese, overseas travel, push and pull factors.

\begin{abstract}
Abstrak
Berwisata saat ini sudah menjadi gaya hidup bagi masyarakat, tak terkecuali orang Bali. Beberapa tahun terakhir tercatat banyak orang Bali yang berlibur, bahkan hingga ke luar negeri. Penelitian ini bertujuan untuk mengetahui profil demografis orang Bali dan negara yang dikunjungi, faktor pendorong dan penarik, menganalisis tingkat motivasi dan perbedaan motivasi
\end{abstract}


orang Bali yang pertama kali dan yang sering berwisata ke luar negeri. Teori Motivasi dan Teori Hirarki Kebutuhan Maslow digunakan dalam penelitian ini. Pengumpulan data menggunakan metode wawancara dan kuesioner dengan teknik Quota Sampling. Teknik analisis data dilakukan dengan analisis deskriptif kualitatif dan analisis statistik Diskriminan. Hasil penelitian menunjukkan bahwa motivasi orang Bali sangat beragam, responden dapat memiliki motivasi lebih dari satu. Faktor pendorong yang paling dominan adalah educational opportunity disamping motif lain seperti relaxation dan play, sedangkan faktor penarik yang dominan adalah cultural factors, diikuti oleh natural environment dan recreation and attraction services. Ditemukan pula adanya perbedaan motivasi di antara orang Bali yang pertama kali dan yang sering melakukan perjalanan wisata ke luar negeri.

Kata kunci: motivasi berwisata, orang Bali, wisata ke luar negeri, faktor pendorong dan faktor penarik.

\section{Pendahuluan}

Berwisata saat ini sudah menjadi gaya hidup bagi masyarakat di berbagai negara, termasuk masyarakat Bali. Adanya perbaikan di bidang pendidikan, kesehatan, dan perbaikan pendapatan telah mendorong perubahan untuk lebih menyukai kegiatan bersenang-senang atau berwisata dibandingkan generasi sebelumnya (Utama, 2011). Tujuan perjalanan yang dilakukan karena berbagai kepentingan, baik karena sekedar ingin tahu, menambah pengalaman atau untuk belajar, dan mengalami secara langsung segala sesuatu yang tidak ada di tempat tinggalnya baik keunikan alam, budaya maupun kondisi geografis yang berbeda dari tempat tinggalnya. Jajak pendapat secara online yang dilakukan majalah Femina (2016) menyebutkan bahwa liburan/traveling sebagai kebutuhan penting kedua (sebesar 19,96\%) di bawah kebutuhan sandang, pangan dan papan (sebesar 66,98\%) di samping pilihan lain yaitu hobi (binatang peliharaan, otomotif, koleksi unik, dan lainnya), gadget terkini, dan barang fashion bermerek (tas, sepatu, baju, dan lainnya).

Pariwisata sudah menjadi keseharian orang Bali, keterlibatan orang Bali pada industri pariwisata adalah sebagai penyedia layanan bagi wisatawan baik wisatawan lokal maupun wisatawan mancanegara. Keterlibatan orang Bali dalam industri pariwisata saat ini tidak hanya sebagai penyedia jasa pariwisata namun juga sebagai wisatawan. Pendapat yang menyatakan bahwa orang Bali tidak menyukai liburan namun lebih senang mengeluarkan uang untuk kegiatan upacara keagamaan daripada tamasya saat ini mulai 
terbantahkan (Soethama, 2011).

Beberapa tahun terakhir tercatat banyak orang Bali yang mulai berlibur, bahkan hingga ke luar negeri. Ketersediaan daerah tujuan wisata yang begitu banyak dan bervariasi yang ditawarkan industri pariwisata di Bali tidak menyurutkan minat dan keinginan orang Bali untuk mencari alternatif liburan ke luar negeri khususnya ke beberapa negara yang dianggap menjadi destinasi favorit. Data dari beberapa travel agent menggambarkan terjadi peningkatan jumlah orang Bali yang mulai melakukan perjalanan wisata ke luar negeri dan diperkuat oleh data yang dikeluarkan oleh Kantor Imigrasi Kelas I Khusus Ngurah Rai.

Beberapa tahun terakhir Kantor Imigrasi Kelas I Khusus Ngurah Rai mencatat terjadi peningkatan jumlah keberangkatan Warga Negara Indonesia yang melakukan perjalanan ke luar negeri. Pada tahun 2009 tercatat sejumlah 120.509 orang, tahun 2010 tercatat sejumlah 134.456 orang, tahun 2011 tercatat sejumlah 166.109 orang, tahun 2012 tercatat sejumlah 167.328 orang, tahun 2013 tercatat sejumlah 177.303 orang, tahun 2014 tercatat sejumlah 220.928 orang.

Data tersebut adalah jumlah warga Negara Indonesia yang berangkat ke luar negeri tanpa membedakan alamat, suku, maupun agama, namum dapat dijadikan bayangan bahwa di dalamnya termasuk orang Bali. Hal ini diperkuat dengan pengamatan bahwa banyak orang Bali berlibur ke luar negeri dengan tujuan untuk tirta yatra ke India, wisata ke Eropa, Amerika, Australia dan negara lain di Asia khususnya Asia Tenggara. Di Asia Tenggara yang menjadi destinasi wisata favorit adalah Singapura, Malaysia, dan Thailand karena mempunyai jarak yang dekat dan tersedia banyak penerbangan yang menawarkan tiket promo.

Penelitian ini bertujuan untuk mengetahui profil demografis orang Bali yang melakukan perjalanan wisata ke luar negeri dan negara yang dikunjungi, mengetahui faktor pendorong dan penarik yang menjadi motivasi orang Bali melakukan perjalanan wisata ke luar negeri, menganalisis tingkat motivasi orang Bali yang melakukan perjalanan wisata ke luar negeri. Artikel juga menganalisis perbedaan motivasi bagi orang Bali yang pertama kali melakukan perjalanan wisata ke luar negeri dan yang sudah sering melakukan perjalanan wisata ke luar negeri.

\section{Teori dan Metode}

Teori yang digunakan dalam penelitian ini adalah teori motivasi dan Teori Hirarki Kebutuhan Maslow. Menurut Yoon dan Usyal (2003), motivasi perjalanan wisata seseorang dibagi menjadi dua yaitu faktor pendorong dan penarik. Faktor pendorong (push factors) merupakan faktor-faktor yang terkait dengan keinginan seseorang untuk melakukan perjalanan yang berasal dari dalam dirinya (intrinsic motivation), sedangkan faktor penarik 
(pull factors) merupakan faktor eksternal (extrinsic motivation) yang memotivasi wisatawan untuk melakukan perjalanan wisata. Faktor penarik berhubungan dengan kualitas destinasi yang menarik bagi wisatawan (destination-spesific attributes).

Menurut Ryan (1991 dalam Pitana dan Gayatri 2005: 67-68) berbagai faktor pendorong bagi seseorang untuk melakukan perjalanan wisata terdiri atas lain: (1) escape, (2) relaxation, (3) play, (4) strengthening family bonds, (5) prestige, (6) social interaction, (7) romance, (8) educational opportunity, (9) self-fulfilment, dan (10) wish-fulfilment. escape, relaxation, dan play merupkan motivasi yang bersifat fisik karena bertujuan untuk melepaskan diri kejenuhan pekerjaan sehari-hari, relaksasi, dan menikmati kegembiraan melalui berbagai permainan/kegiatan pada destinasi wisata; Strengthening family bonds, social interaction, dan romance merupakan motivasi yang bersifat sosial dengan berbagai kegiatan yang bertujuan untuk mempererat hubungan kekerabatan, melakukan interaksi sosial dengan teman sejawat atau dengan masyarakat lokal yang dikunjungi, dan memenuhi kebutuhan akan kasih sayang dan rasa romantis; Educational opportunity merupakan motivasi yang berkaitan dengan keinginan seseorang untuk melihat sesuatu yang baru, mempelajari orang atau daerah lain, atau untuk mengetahui kebudayaan etnis lain; Prestige merupakan motivasi yang berkaitan dengan keinginan seseorang untuk menunjukkan gengsi, yaitu dengan mengunjungi destinasi yang menunjukkan kelas dan gaya hidup pelakunya; Self-fulfilment merupakan motivasi yang berkaitan dengan keinginan seseorang untuk menemukan diri sendiri (self-discovery); dan Wish-fulfilment merupakan motivasi yang berkaitan dengan keinginan seseorang untuk merealisasikan mimpi-mimpi yang lama dicita-citakan, misalnya keinginan untuk melakukan wisata spiritual.

Faktor penarik (pull factors), menurut Crouch (dalam Kassean dan Gassita 2013), berkontribusi untuk memberikan pengalaman bagi wisatawan baik kesan positif maupun kesan negatif terhadap suatu destinasi. Faktorfaktor tersebut secara komprehensif dirangkum dengan berbagai faktor yang bersama-sama berkontribusi untuk destinasi wisata. Faktor-faktor penarik tersebut adalah service infrastructure dan destination environment. Service infrastructure terdiri atas : (1) transportation and travel services, yaitu layanan di bidang perjalanan dan transportasi bagi wisatawan misalnya jalan raya, rel kereta api, bandara, laut serta terminal atau stasiun; (2) accommodation services, yaitu layanan di bidang akomodasi/jasa pelayanan penginapan bagi wisatawan; (3) recreation and attraction services, yaitu fasilitas dan layanan pada saat penyelenggaraan atraksi wisata dan rekreasi bagi wisatawan; (4) shopping services, yaitu fasilitas dan layanan yang diberikan untuk aktivitas berbelanja bagi wisatawan; dan (5) food and beverage services, yaitu fasilitas dan layanan yang diberikan destinasi 
dengan berbagai sajian makanan dan minuman bagi wisatawan.

Destination environment terdiri atas: (1) natural environment, yang merupakan daya tarik alami destinasi berupa natural resources yaitu iklim, pantai, alam pedesaan (flora dan fauna, taman, danau, gunung) yang dimanifestasikan dalam bentuk pemandangan alam, kebersihan lingkungan, polusi, kemacetan dan kebisingan; (2) political and legal factors, yang merupakan daya tarik destinasi di bidang stabilitas politik yang memberikan jaminan keamanan dan kenyamanan wisatawan pada destinasi; (3) technological factors, yang merupakan daya tarik karena teknologi yang dimiliki destinasi; (4) Cultural factors, yang merupakan daya tarik budaya yang dimiliki destinasi, biasanya dalam bentuk festival, kerajinan, agama, adat istiadat, dan bangunan sejarah; (5) social factors, yang merupakan daya tarik sosial yang dimiliki destinasi dalam bentuk bahasa, kualitas hidup, dan keramahtamahan penduduknya; dan (6) economic factors, yang merupakan daya tarik ekonomi yang dimiliki destinasi dalam bentuk harga-harga yang terjangkau bagi wisatawan.

Secara intrinsik, motivasi terbentuk karena adanya kebutuhan dan/atau keinginan dari manusia. Teori ini dikemukakan oleh Abraham A. Maslow yang menyatakan bahwa manusia dimotivasi untuk memuaskan sejumlah kebutuhan yang melekat pada diri setiap manusia yang cenderung bersifat bawaan (Hariandja, 2007:324). Menurut Maslow, kebutuhan manusia berjenjang atau bertingkat, mulai dari tingkatan yang paling rendah yaitu kebutuhan fisik, rasa aman, sosial, pengakuan sampai dengan kebutuhan tertinggi yaitu kebutuhan aktualisasi diri.

Kebutuhan fisik (physiological need), kebutuhan ini berkaitan dengan kebutuhan yang harus dipenuhi untuk mempertahankan diri sebagai makhluk fisik; Kebutuhan rasa aman (safety needs), kebutuhan ini berkaitan dengan kebutuhan rasa aman ancaman-ancaman dari luar yang mungkin terjadi; Kebutuhan sosial (social needs), kebutuhan ini berkaitan dengan menjadi bagian dari orang lain yaitu kebutuhan manusia untuk berinteraksi, berinterrelasi dan berafiliasi dengan orang lain; Kebutuhan pengakuan (esteem needs), kebutuhan yang berkaitan tidak hanya menjadi bagian orang lain (masyarakat), tetapi lebih jauh dari itu, yaitu diakui/dihormati/dihargai orang lain karena kemampuannya atau kekuatannya; dan Kebutuhan aktualisasi diri (self actualization needs), kebutuhan yang berhubungan dengan aktualisasi/penyaluran diri dalam arti kemampuan/minat/potensi diri dalam bentuk nyata dalam kehidupannya.

Berdasarkan teori tersebut, maka setiap manusia terdorong melakukan perjalanan untuk memenuhi kebutuhannya, antara lain : (1) kebutuhan dagang atau ekonomi; (2) kebutuhan politik; (3) kebutuhan keamanan; (4) kebutuhan kesehatan dan kecantikan; (5) kebutuhan pemukiman; (6) kebutuhan keagamaan; (7) kebutuhan pendidikan atau penelitian; (8) 
kebutuhan minat budaya; (9) kebutuhan hubungan keluarga; (10) kebutuhan rekreasi atau liburan; (11) kebutuhan konvensi dan pameran; (12) kebutuhan olahraga; (13) dan kebutuhan dinas (Muljadi, 2014:6).

Penelitian dilakukan dengan menyebarkan 350 lembar kuesioner di kalangan pengguna jasa travel agent. Responden diminta untuk mengisi kuesioner pada saat melakukan pembookingan tiket pada travel agent. Kuesioner tersebut berisi sejumlah pertanyaan tentang identitas diri responden yang menjelaskan beberapa karakteristik responden antara lain: jenis kelamin, alamat, umur, status perkawinan, pendidikan, pekerjaan, tujuan melakukan perjalanan, negara yang dikunjungi, jumlah perjalanan wisata yang telah dilakukan, besarnya penghasilan per bulan dan beberapa data terkait yang menggambarkan informasi lebih mendalam pada karakteristik responden seperti apakah perjalanan wisata ke luar negeri sudah menjadi acara rutin, waktu yang dihabiskan selama di luar negeri, dengan siapa melakukan perjalanan, dan pilihan perjalanan apakah dengan travel agent atau independent travel. Teknik pengumpulan data dilakukan dengan metode survei (kuesioner), wawancara dan studi kepustakaan, sedangkan metode penentuan responden dilakukan dengan metode sampel nonprobabilitas dengan teknik quota sampling. Selanjutnya akan dianalisis dengan teknik analisis data deskriptif kualitatif dan analisis statistik yaitu analisis diskriminan/discriminant analysis.

\section{Profil Demografis dan Negara yang Dikunjungi}

Responden dalam penelitian ini berjumlah 350 orang, terdiri atas dua kelompok yaitu orang Bali yang pertama kali melakukan perjalanan wisata ke luar negeri dan orang Bali yang melakukan perjalanan wisata ke luar negeri lebih dari satu kali. Profil demografis responden akan diuraikan berdasarkan informasi yang telah diisi responden pada lembar kuesioner yang mencakup tentang data-data pribadi responden yang meliputi jenis kelamin, umur, pendidikan, pekerjaan, dan besarnya penghasilan per bulan.

Berdasarkan jenis kelamin, jumlah responden yang berjenis kelamin perempuan dan laki-laki yang melakukan perjalanan wisata ke luar negeri hampir sama yaitu sebanyak 181 orang atau $51,7 \%$ responden perempuan dan 169 orang atau $48,3 \%$ responden laki-laki.

Berdasarkan umur, hasil penelitian menunjukkan bahwa responden terbanyak yang melakukan perjalanan wisata ke luar negeri adalah responden pada kelompok umur 30-34 tahun yaitu sejumlah 61 orang $(17,4 \%)$ dan responden yang paling sedikit berada pada kelompok 5-9 tahun yaitu sejumlah 1 orang $(0,3 \%)$.

Dilihat dari pendidikan terakhir yang telah ditamatkan, pendidikan responden dalam penelitian ini sangat bervariasi dan rata-rata berpendidikan tinggi. Ditemukan bahwa sebagian besar responden yang melakukan 
perjalanan wisata ke luar negeri adalah responden yang telah menamatkan pendidikan strata satu (S1) yaitu sebanyak 159 orang $(45,4 \%)$.

Berdasarkan pekerjaan, orang Bali yang melakukan perjalanan wisata ke luar negeri berasal dari beragam profesi dan responden yang lebih dominan adalah pekerja terampil. Sebagian besar responden merupakan Pegawai Negeri Sipil (PNS/Pegawai Kantor Pemerintahan) yaitu 131 orang (37,4\%), dibandingkan dengan responden lain yang mempunyai pekerjaan sebagai wiraswasta, karyawan BUMD, karyawan swasta, pelajar/mahasiswa/ karyasiswa, dosen, dokter, guru, pensiunan, agen asuransi, akuntan publik dan TNI/Polri.

Berdasarkan penghasilan per bulan, hasil penelitian menunjukkan bahwa responden terbanyak berada pada kelompok dengan penghasilan per bulan Rp. 3.000.000 sampai dengan Rp. 5.000.00o yaitu sebanyak 177 orang (50,6\%), sedangkan untuk kelompok lainnya sebanyak 30 orang mengisi dengan jawaban belum berpenghasilan dan 1 orang mengisi dengan jawaban berpenghasilan lebih kecil dari Rp. 3.00o.0oo,-. Tujuan perjalanan wisata yang dilakukan responden selain liburan juga dilakukan dengan tujuan bisnis, tugas kantor, dan tujuan lainnya seperti misi kesenian dan studi tour, sehingga biaya perjalanannya tidak hanya berasal dari biaya sendiri, tetapi juga dibiayai dari kantor dan biaya lainnya yaitu berasal dari sponsor, sedangkan 30 orang yang belum berpenghasilan adalah pelajar yang perjalanannya dibiayai oleh orang tua.

Perjalanan wisata dipengaruhi oleh beberapa faktor. Salah satunya adalah gaya hidup (lifestyle) yang meliputi: (1) pendapatan dan pekerjaan; (2) Hak cuti kerja; (3) Pendidikan dan mobility; dan (4) Ras dan Jenis Kelamin (Suwena dan Widyatmaja, 2010). Ditinjau dari pendapatan dan pekerjaan, rata-rata responden memiliki pendapatan yang baik dengan jenis pekerjaan menunjukkan bahwa responden yang lebih dominan adalah pekerja terampil yaitu pekerja pada jenis pekerjaan profesional, kepemimpinan tata laksana dan tata usaha, seperti dosen, dokter, guru, akuntan publik, Pegawai Negeri Sipil (PNS/Pegawai Kantor Pemerintahan), karyawan BUMD, karyawan swasta, dan TNI/Polri. Ditinjau dari hak cuti kerja, responden merupakan pekerja yang bisa mendapatkan cuti kerja sehingga cenderung memiliki waktu luang untuk berwisata. Ditinjau dari pendidikan dan mobilitas, ratarata responden memiliki pendidikan yang baik karena telah menamatkan pendidikan strata satu (S1) dan adanya promosi tiket murah dari maskapai penerbangan juga turut mempengaruhi kecenderungan orang melakukan perjalanan wisata ke luar negeri. Ditinjau dari ras dan jenis kelamin, ada kecenderungan sekarang ini, perjalanan wisata tidak hanya didominasi oleh orang-orang dari benua Eropa, Australia atau Amerika saja, orang Asia pun sudah banyak yang melakukan perjalanan wisata, termasuk orang Bali. Hasil penelitian ini menunjukkan bahwa responden terbanyak yang melakukan 


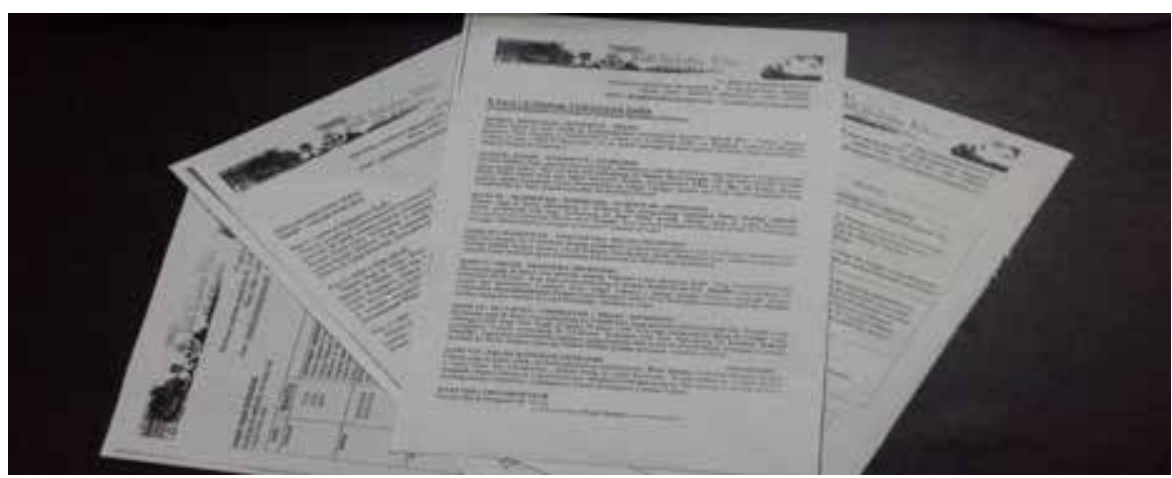

DOKUMENTASI PENULIS

Foto 1. Brosur paket tour ke luar negeri.

perjalanan wisata adalah perempuan dengan pekerjaan dan penghasilan yang baik. Hal ini menunjukkan bahwa perempuan yang bekerja merupakan pangsa pasar yang sangat potensial sebagai promosi pariwisata.

Negara-negara utama yang menjadi tujuan perjalanan wisata bagi orang Bali masih berada di benua Asia, dengan negara yang paling banyak dikunjungi adalah Singapura yang dikunjungi oleh 247 orang responden (34,74\%). Pemilihan destinasi bagi responden didasarkan pada kemampuan keuangan, jarak dan kepopuleran destinasi. Menurut Andri Marini pengelola travel agent di Denpasar (Wawancara, 18/01/2016), pengguna jasa travel agent melakukan perjalanan wisata ke luar negeri karena ketertarikan yang sangat besar untuk mengetahui tempat wisata di mancanegara akibat dari pemberitaan media yang semakin gencar tentang tempat wisata yang menarik di luar negeri. Wisatawan umumnya mencari destinasi wisata yang sudah terkenal (populer) dan sedang tren seperti Singapura, Malaysia, Thailand, Cina atau Korea Selatan.

Responden juga sering memanfaatkan promosi paket perjalanan wisata ke luar negeri yang relatif lebih murah dari paket wisata dalam negeri. Menurut penuturan Luh Henny (wawancara, 07/01/2016), pengelola sebuah travel agent di Denpasar, masyarakat Bali masih mempercayai travel agent untuk mengelola perjalanan wisata mereka sehingga perjalanan wisata ke luar negeri merupakan lahan bisnis yang menjanjikan. Berdasarkan data yang diperoleh sebanyak 226 orang $(64,26 \%)$ memilih melakukan perjalanan wisata menggunakan jasa travel agent. Kemudahan yang ditawarkan travel agent dalam hal pengurusan dokumen wisata seperti visa dan promosi paket perjalanan wisata ke luar negeri yang relatif lebih murah dari paket wisata dalam negeri juga turut menjadi alasan wisatawan memilih liburan di luar negeri dan menggunakan jasa travel agent. 


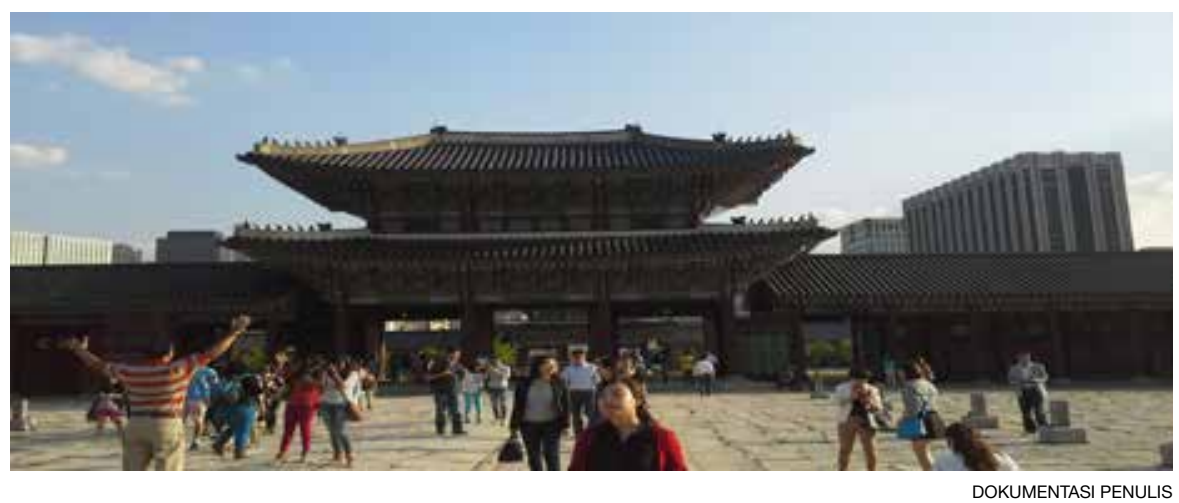

Foto 2. Aktivitas orang Bali di Korea Selatan.

\section{Faktor Pendorong dan Penarik Perjalanan Wisata}

Seseorang melakukan perjalanan wisata ke suatu destinasi disebabkan oleh faktor-faktor yang mendorong (push factors) dari dalam diri sendiri dan faktor-faktor yang menarik (pull factors) yang berasal dari daya tarik destinasi yang mereka kunjungi. Untuk mengetahui motivasi pendorong orang Bali melakukan perjalanan wisata ke luar negeri, pada lembar kuesioner telah disediakan 13 pilihan jawaban yang dapat dipilih oleh responden. Responden dipersilahkan memilih lebih dari satu pada jawaban yang tersedia yaitu escape, relaxation, play, strengthening family bonds, prestige, social interaction, romance, educational opportunity, selffulfilment, dan wish-fulfilment ditambah tiga pilihan lain yaitu kesehatan, pekerjaan dan pilihan lainnya yang dapat diisi oleh sendiri oleh responden. Hasil pengisian kuesioner menunjukkan bahwa motivasi pendorong yang paling banyak adalah educational opportunity, diikuti oleh relaxation, play, escape, self-fulfilment, pekerjaan, social interaction, wish-fulfilment, strengthening family bonds, motivasi lainnya, romance, kesehatan dan yang paling akhir adalah prestige. Motivasi lainnya yang disebutkan oleh responden adalah misi kesenian, study tour, karena mendapat hadiah paket wisata dari kantor dan menang kuis.

Motivasi yang menjadi pendorong orang Bali melakukan perjalanan ke luar negeri sangat beragam, 1 orang responden dapat memiliki motivasi lebih dari satu. Hal ini sesuai dengan pernyataan Krippendorf (1997 dalam Pitana dan Gayatri 2005:61) bahwa motivasi seorang wisatawan melakukan perjalanan sangat bervariasi dan tidak selalu bersifat tunggal, melainkan kombinasi dari berbagai motivasi. Hasil penelitian menunjukkan bahwa motivasi terbanyak orang Bali melakukan perjalanan wisata ke luar negeri adalah educational opportunity disamping adanya kebutuhan lain yang juga ingin dipuaskan seperti relaxation, play, escape, self-fulfilment, pekerjaan, social interaction, wish-fulfilment, strengthening family bonds, motivasi 
lainnya, romance, kesehatan dan prestige.

Analisis terhadap motivasi intrinsik dilakukan menggunakan teori Maslow menunjukkan bahwa orang Bali yang melakukan perjalanan ke luar negeri sudah melalui dua tingkatan dari lima tingkatan kebutuhan yang ada yaitu kebutuhan fisik (psysiological needs) dan kebutuhan rasa aman. Kebutuhan fisik, berkaitan dengan berbagai kebutuhan fisiologis yang harus dipenuhi untuk kelangsungan hidup yaitu kebutuhan primer berupa kebutuhan makan, minum, pakaian dan sebagainya. Selanjutnya kebutuhan yang juga telah dipenuhi adalah kebutuhan rasa aman. Kebutuhan tersebut dapat berupa adanya rasa aman dan tidak ada beban meninggalkan rumah dan keluarganya di Bali untuk melakukan perjalanan wisata yang jauh (ke luar negeri) dan adanya jaminan bahwa penghasilan yang dipereleh mampu membiayai perjalanan yang dilakukan.

Setelah kebutuhan fisik dan rasa aman terpenuhi, maka diikuti oleh kebutuhan berikutnya yaitu kebutuhan sosialisasi, pengakuan dan aktualisasi. Motivasi yang menjadi pendorong orang Bali melakukan perjalanan ke luar negeri termasuk ke pemenuhan kebutuhan sosial, pengakuan dan aktualisasi diri antara lain: (1) Kebutuhan sosial, yaitu ditandai dengan adanya keinginan seseorang untuk bersosialisasi dengan teman seperjalanan atau penduduk yang ditemui dan bertemu teman (social interaction dan strengthening family bonds), melakukan aktivitas penuh kegembiraan (play), dan memenuhi kebutuhan akan kasih sayang dan rasa romantis (romance); (2) Kebutuhan akan pengakuan, yang dapat berupa pengakuan akan kelas dan gaya hidup yang ditunjukkan dengan oleh kemampuan dan kemauan orang Bali melakukan perjalanan wisata ke luar negeri. Pemenuhannya kebutuhan akan pengakuan ditunjukkan oleh kegiatan untuk liburan yaitu keinginan untuk relaksasi atau penyegaran (relaxation dan escape) dengan mengunjungi destinasi wisata ke luar negeri maupun untuk pemenuhan kebutuhan kesehatan melalui kegiatan wisata kesehatan ke luar negeri yang menunjukkan prestise dan status pelakunya; dan (3) Kebutuhan aktualisasi diri dari orang Bali ditandai dari keinginan untuk memenuhi kebutuhan aktualisasi diri/penyaluran diri dalam arti kemampuan/minat/potensi diri dapat dilihat dari adanya keinginan untuk mengembangkan wasawan.

Pemenuhan kebutuhan aktualisasi diri ditunjukkan oleh adanya perjalanan wisata yang dilakukan untuk memenuhi keinginan melihat sesuatu yang baru, mempelajari sesuatu, orang atau daerah lain, atau untuk mengetahui kebudayaan etnis lain (educational opportunity), adanya keinginan untuk menemukan jati diri/self-discovery (self-fulfilment), dan adanya keinginan untuk melakukan pemenuhan kebutuhan keagamaan yang dilakukan melalui perjalanan wisata religius (wish-fulfilment), memenuhi tugas kantor/pekerjaan yang berhubungan dengan aktivitas 
untuk meningkatkan kemampuan/mengembangkan wawasan (kursus singkat, mengajar, seminar, studi banding, training, dan study tour).

Untuk mengetahui motivasi ekstrinsik responden (faktor penarik), pada lembar kuesioner disediakan 12 jawaban yang dapat diisi oleh responden. Responden dapat memilih lebih dari satu pada jawaban yang tersedia yaitu transportation and travel services, accommodation services, recreation and attraction services, shopping services, food and beverage services, natural environment, political and legal factors, technological factors, cultural factors, social factors, economic factors, dan pilihan lainnya yang dapat disebutkan sendiri oleh responden.

Hasil pengisian kuesioner menunjukkan bahwa daya tarik destinasi terbesar yang memotivasi responden ke luar negeri adalah cultural factors, diikuti oleh natural environment, recreation and attraction services, transportation and travel services, technological factors, shopping services, economic factors, accommodation services, food and beverage services, political and legal factors, socialfactors, dan terakhir adalah pilihan lainnya. Motivasi lainnya yang disebutkan oleh responden adalah menonton konser musik dan ingin mengetahui kemajuan di bidang pendidikan.

\section{Tingkat motivasi orang Bali}

Secara umum tingkat motivasi orang Bali yang melakukan perjalanan wisata ke luar negeri berada pada tingkat tinggi dengan nilai rata-rata pada variabel push factor dan pull factor adalah 3,51. Responden memberikan nilai pada level rendah hanya pada 1 variabel faktor pendorong yaitu prestige; nilai pada level sedang pada 5 variabel faktor pendorong yaitu romance, strengthening family bonds, social interaction, wish-fulfilment, dan self-fulfilment dan 3 variabel faktor penarik yaitu shopping service, food and beverage services, dan social factors; dan pada level tinggi pada 4 variabel faktor pendorong yaitu relaxation, escape, play, dan educational opportunity dan pada 8 variabel faktor penarik yaitu economic factors, accommodation services, transportation and travel services, political and legal factors, technological factors, recreation and attraction services, cultural factors, dan natural environment.

Nilai rata-rata pada variabel faktor pendorong lebih kecil dibandingkan nilai rata-rata pada variabel faktor penarik. Hal ini menunjukkan bahwa motivasi intrinsik responden lebih rendah jika dibandingkan motivasi ekstrinsik, artinya faktor-faktor yang lebih memotivasi orang Bali ke luar negeri adalah daya tarik destinasi wisata di luar negeri (pull factor) baik dari kualitas layanan, daya tarik lingkungan destinasi maupun kelebihankelebihan lain yang dimiliki. Di samping itu ada faktor-faktor determinan yang menyebabkan seseorang memutuskan untuk tidak melakukan perjalanan wisata secara intensif atau sama sekali tidak melakukan 
perjalanan yaitu alasan tidak adanya waktu dan tidak cukupnya biaya untuk melakukan perjalanan (Suwena dan Widyatmaja, 2010).

Beberapa responden menyatakan bahwa perjalanan wisata ke tidak selalu dapat diwujudkan meskipun keinginan untuk melakukan perjalanan wisata ke luar negeri selalu ada. Ada saja kedala yang menyebabkannya menunda keinginan untuk melakukan perjalanan wisata ke luar negeri. Salah satunya adalah tidak cukupnya biaya untuk melakukan perjalanan. Ada pertimbangan lain atau sesuatu yang lebih penting dan mendesak yang harus diutamakan daripada untuk melakukan perjalanan wisata, sehingga perjalanan wisata yang dilakukannya akan disesuaikan dengan dana dan waktu yang ada karena memerlukan perencanaan yang lebih matang dibandingkan dengan perjalanan yang dilakukan di dalam negeri. Data ini diperkuat oleh temuan yaitu sebanyak 304 orang atau 86,9\% responden menyatakan perjalanan wisata ke luar negeri bukan agenda rutin.

Nilai rata-rata tertinggi pada variabel pendorong adalah educational opportunity (X1.8). Hal ini sesuai dengan harapan responden yang rata-rata menyatakan ingin melihat negara lain secara langsung untuk mengetahui kondisi negara tersebut terutama budaya, destinasi wisata, kemajuan dan merasakan langsung atmosfir yang baru dan berharap dapat menambah wawasan.

Diantara 8 variabel faktor penarik yang berada pada level tinggi, daya tarik destinasi yang dinilai paling tinggi adalah natural environment (X2.6). Hal ini sesuai dengan kesan-kesan yang diberikan responden yang menyatakan bahwa sangat terkesan dengan kebersihan lingkungan, pengelolaan sampah yang dirasa lebih baik dari Indonesia, melihat dan merasakan secara langsung musin salju yang tidak pernah ditemui di Bali. Bali dengan iklim laut tropisnya mendorong orang Bali untuk melakukan perjalanan wisata ke negara yang mempunyai iklim yang berbeda dari daerah asalnya (inversi secara geografik). Kegiatan pariwisata pada hakikatnya merupakan inversi (ritual inversion), yaitu melakukan atau mendapatkan hal-hal yang berlawanan dengan apa yang biasa didapatkan di daerah asal (Pitana dan Gayatri, 2005).

Variabel social interaction (X1.6) dan social factors (X2.9) berada pada level sedang. Hal ini sesuai dengan kesan-kesan responden yang menyatakan adanya kendala bahasa yang menyebabkan komunikasi dengan penduduk lokal sangat terbatas dan menurut responden masyarakat di negara yang pernah dikunjungi kurang ramah dan terkesan sangat individualis.

Variabel prestige merupakan satu-satunya variabel yang berada pada level rendah. Hal ini disebabkan karena proses pengambilan keputusan orang Bali melakukan perjalanan ke luar negeri tidak hanya ditentukan oleh karakteristik sosial dan ekonomi, tetapi juga karakteristik perilaku (sikap dan nilai yang dianut). Mengunjungi destinasi wisata di luar negeri merupakan 
sesuatu yang menunjukkan kelas dan gaya hidup, namun karakteristik orang Bali yang lebih senang mengeluarkan uang untuk kegiatan keagamaan menunjukkan bahwa perjalanan wisata ke luar negeri bukan menjadi tujuan utama. Prestige ditunjukkan oleh beberapa pelaksanaan upacara di Bali. Salah satu pelaksanaan upacara di Bali yang menunjukkan prestige adalah pelaksanaan pelebon di puri Ubud berlangsung mewah, megah, dan meriah yang ditunjukkan dengan penggunaan bade yang menjulang dan menggunakan Naga Banda (Sujaya, 2013).

Ada 8 variabel faktor penarik yang berada pada level tinggi, hal ini menunjukkan bahwa atribut-atribut destinasi wisata di luar negeri sesuai dengan harapan orang Bali. Atribut-atribut tersebut adalah infrastruktur pariwisata, daya tarik wisata, pengalaman perjalanan wisata dari Bali dan ke destinasi tujuan, dan ketersediaan berbagai fasilitas pariwisata.

\section{Perbedaan Motivasi Orang Bali}

Analisis diskriminan menggunakan skor masing-masing variabel pada tingkat motivasi intrinsik (faktor pendorong) dan motivasi ekstrinsik (faktor penarik) dengan tingkat signifikansi sebesar 95\% (error level = 0,05), digunakan untuk mengetahui perbedaan motivasi diantara kelompok orang Bali yang baru pertama kali dan yang sudah sering melakukan perjalanan wisata ke luar negeri.

Perbedaan pada motivasi intrinsik (faktor pendorong) ditunjukkan oleh variabel play (X1.3) dan educational opportunity (X1.8) dapat dilihat dalam bentuk perbedaan skor yang ditunjukkan oleh nilai sig. pada variabel play (X1.3) sebesar 0,003 dan educational opportunity (X1.8) sebesar 0,005. Perbedaan motivasi pada variabel play (X1.3) berdasarkan pengalaman dan kesan yang dirasakan responden. Umumnya responden melakukan perjalanan berulang karena banyak aktivitas penuh kegembiraan yang dapat dilakukan di luar negeri misalnya menonton konser musik, menonton live motogp, mengunjungi tempat wisata dunia, foto selfi di tempat wisata yang menjadi ikon pada negara yang dikunjungi, dan mencari area permainan yang hanya ada di luar negeri seperti Universal Studio. Sementara itu pada variabel educational opportunity (X1.8), responden cenderung melakukan perjalanan ke luar negeri karena memiliki kesempatan atau keinginan untuk menambah pengetahuan dan memang harus belajar ke luar negeri dengan mengikuti pelatihan, kursus singkat dan seminar. Banyak tempat di luar negeri yang mempunyai nilai sejarah, budaya, tradisi dan teknologi yang bisa dilihat dan dipelajari. Hal ini dapat dilihat dari hasil penelitian, yang menunjukkan bahwa tujuan perjalanan wisata ke luar negeri dilakukan disamping untuk liburan, juga didominasi oleh kegiatan untuk belajar atau meningkatkan pengetahuan dan keterampilan seperti kursus singkat, seminar, studi banding, training, dan studi tour. 
Perbedaan pada motivasi ekstrinsik yang ditunjukkan pada variabel food and beverage services (X2.5) ditunjukkan dengan nilai sig. sebesar 0,047. Perbedaan pengalaman dan kesan yang dirasakan responden pada variabel food and beverage services (X2.5) disebabkan oleh perbedaan selera responden. Umumnya responden yang sudah sering melakukan perjalanan ke luar negeri lebih sering menikmati berbagai menu makanan yang berbeda pada tiap negara yang dikunjungi dan selalu ingin mencari makanan khas setiap negara yang dikunjungi, sedangkan responden orang Bali yang baru pertama kali melakukan perjalanan wisata ke luar negeri mempunyai kesan yang kurang menyenangkan terhadap makanan yang sempat dicicipi selama di luar negeri.

\section{Simpulan}

Berdasarkan uraian di atas dapat disimpulkan beberapa hal sebagai berikut.

Pertama, profil demografis orang Bali yang melakukan perjalanan wisata ke luar negeri didapatkan bahwa responden terbanyak yang melakukan perjalanan wisata ke luar negeri diketahui berada pada kelompok umur 30-34 tahun sebanyak 61 orang $(17,4 \%)$; responden telah menamatkan pendidikan strata satu (S1) sebanyak 159 orang (45,4\%); sebagian besar responden merupakan Pegawai Negeri Sipil (PNS/ Pegawai Kantor Pemerintahan) yaitu sebanyak 131 orang (37,4\%); dan penghasilan responden terbanyak berada pada kelompok dengan penghasilan per bulan Rp. 3.0oo.ooo sampai dengan Rp. 5.0oo.ooo sebanyak 177 orang (50,6\%). Negara-negara utama yang menjadi tujuan perjalanan wisata bagi orang Bali masih berada di Benua Asia, dengan negara yang paling banyak dikunjungi adalah Singapura yang dikunjungi oleh 247 orang responden (34,74\%).

Kedua, motivasi yang menjadi pendorong (push factors) dan penarik (pull factors) orang Bali melakukan perjalanan ke luar negeri sangat beragam, ditemukan bahwa responden memiliki motivasi lebih dari satu. Sebanyak 179 orang atau 51,1\% responden menyatakan bahwa motivasi utama yang menjadi pendorong orang Bali melakukan perjalanan ke luar negeri adalah educational opportunity diikuti oleh motif relaxation, play, dan yang terakhir adalah prestige, sedangkan sebanyak 168 orang atau 48,8\% responden menyatakan bahwa daya tarik destinasi terbesar yang memotivasi responden ke luar negeri adalah cultural factors, diikuti oleh motif natural environment, recreation and attraction services.

Ketiga, secara umum tingkat motivasi orang Bali yang melakukan perjalanan wisata ke luar negeri berdasarkan nilai rata-rata pada variabel faktor pendorong (push factors) dan penarik (pullfactors) berada pada level tinggi dengan nilai 3,51.

Keempat, secara umum terdapat perbedaan motivasi antara orang 
Bali yang pertama kali melakukan perjalanan wisata ke luar negeri dan yang sudah sering melakukan perjalanan wisata ke luar negeri. Pada faktor pendorong disebabkan karena responden ingin melakukan aktivitas penuh kegembiraan (play) dan menambah pengetahuan dan keterampilan (educational opportunity), sedangkan pada faktor penarik disebabkan karena perbedaan selera responden pada makanan yang sempat dicicipi selama berada di luar negeri (food and beverage).

\section{Ucapan Terima Kasih}

Penulis menyampaikan ucapkan terima kasih kepada Prof. Dr. I Nyoman Darma Putra, M.Litt. selaku Ketua Program Studi Magister Kajian Pariwisata, Program Pascasarjana Universitas Udayana. Prof. Made Sudiana Mahendra, MApp.Sc., PhD, pembimbing I yang dengan penuh perhatian telah memberikan dorongan, semangat, bimbingan dan saran selama penulisan tesis ini. Dr. Ir. A.A.P. Agung Suryawan Wiranatha, M.Sc, pembimbing II yang dengan penuh perhatian dan kesabaran telah memberikan bimbingan dan saran kepada penulis. Prof. Dr. Ir. Made Antara, MS, Dr. Ir. Syamsul Alam Paturusi, M.SP, dan Dr. I Wayan Suardana, SST.Par, M.Par, selaku dosen penguji yang telah memberikan masukan, saran dan koreksi untuk menyempurnakan tesis ini.

\section{Daftar Pustaka}

Femina, 2016. Apa Kebutuhan Primer Anda? Available from: http://www.femina. co.id/polling/

Hariandja, Marihot Tua Efendi. 2007. Manajemen Sumber Daya Manusia Pengadaan, Pengembangan, Pengkompensasian, dan Peningkatan Produktivitas Pegawai. Cetakan keempat. Jakarta: PT Grasindo.

Kantor Imigrasi Kelas I Khusus Ngurah Rai, Jumlah Keberangkatan Warga Negara Indonesia yang Melakukan Perjalanan ke Luar Negeri melalui Tempat Pemeriksaan Imigrasi (TPI) Bandara Internasional Ngurah Rai Periode Tahun 2009 sampai dengan Maret 2015.

Kassean, Hemant. 2013. "Exploring Tourists Push and Pull Motivations to Visit Mauritius as a Tourist Destination”, African Journal of Hospitality, Tourism and Leisure Vol: 2 (3).

Muljadi, A.J. dan Warman, Andri. 2014. Kepariwisataan dan Perjalanan, Edisi Revisi. Jakarta: PT. Raja Grafindo Persada.

Pitana, I Gde dan Gayatri, Putu G. 2005. Sosiologi Pariwisata.Yogyakarta: Andi Soethama, Gde Aryantha. 2011. Jangan Mati di Bali: Tingkah Polah Negeri Turis. Edisi Pertama. Jakarta: PT Kompas Media Nusantara.

Sujaya, I Made. 2013, Mengapa "Pelebon" Bangsawan Bali Menggunakan Naga Banda?. Available from: https://www.balisaja.com/2013/11/mengapapelebon-bangsawan-bali.html 
Suwena, I Ketut dan Widyatmaja, I Gst Ngr. 2010. Pengetahuan dasar Ilmu Pariwisata. Edisi pertama. Denpasar: Udayanan University Press

Utama, I Gusti Bagus Rai. 2011. Global Tourism: Trend, Perilaku Wisatawan Usia Lanjut dalam Memilih Aktivitas Wisata Available from: https://tourismbali. wordpress.com/2011/o7/18/global-tourism-trend-perilaku-wisatawan-usialanjut-dalam-memilih-aktivitas-wisata/

Yoon, Yooshik dan Uysal, Muzaffer. 2005. An examination of the effects of motivation and satisfaction on destination loyalty: a structural model. Tourism Management 26, Pages 45-56, 2005

\section{Profil Penulis}

Ni Wayan Ana Pradnya Dewi, ST adalah mahasiswa Magister Kajian Pariwisata di Universitas Udayana Denpasar Bali. Menyelesaikan jenjang S1 Teknik Informatika pada Universitas Pembangunan Nasional "Veteran"Yogyakarta. Saat ini menjadi staf pada Biro Aset Setda Provinsi Bali. Email: anapradnya1981@yahoo.com

Made Sudiana Mahendra, Guru Besar di Program Studi Doktor Ilmu Lingkungan, Program Pascasarjana UNUD. Ia menyelesaikan Pendidikan S1 di Jurusan Teknologi Pertanian, Fakultas Pertanian Unud Tahun 1981, S2 dan S3 di Department of Food Science and Technology, The University of New South Wales, Sydney, Australia masing-masing pada tahun Tahun 1986 dan 1991. Selama periode 1992-2008 sebagai adviser dari proyek IAEUP, AAECP, BUIP-TOEM, IHDUA, dan JICA. Sejak 2008 hingga sekarang sebagai adviser Bidang Lingkungan untuk GEB, KHE dan JEI. Pernah menjabat sebagai PD II FP tahun 1994-1997, Kapuslit CeReTroF UNUD tahun 2000-2009, Kaprodi Magister Ilmu Lingkungan PPs UNUD tahun 2010-2013, dan sejak 2014 menjabat sebagai Asdir II PPs UNUD. Email: mahendramade@ yahoo.com

Agung Suryawan Wiranatha memperoleh gelar Master dibidang Environmental Management dari Griffith University, Australia dan gelar Doktor di bidang Regional Planning dari University of Queensland, Australia. Menjadi dosen di Universitas Udayana sejak tahun 1989. Saat ini sedang menjabat sebagai Kepala Pusat Penelitian Kebudayaan dan Kepariwisataan Universitas Udayana sejak tahun 2004, sebagai Sekretaris Program Studi Doktor (S3) Pariwisata Universitas Udayana sejak tahun 2010, dan sebagai Ketua Konsorsium Riset Pariwisata sejak tahun 2013. Banyak melakukan riset kebijakan dan perencanaan pembangunan kepariwisataan di Bali maupun di Indonesia. Email: balitruly@yahoo.com 